Research Report No. 14/2012

\title{
The Embededness of Responsible Business Practice: National Institutional Environments and Corporate Social Responsibility
}

Luc Fransen

Follow this and additional works at: http://digitalcommons.osgoode.yorku.ca/clpe

\section{Recommended Citation}

Fransen, Luc, "The Embededness of Responsible Business Practice: National Institutional Environments and Corporate Social Responsibility" (2012). Comparative Research in Law \& Political Economy. Research Paper No. 14/2012.

http://digitalcommons.osgoode.yorku.ca/clpe/17 


\title{
OSGOODE
}

OSGOODE HALL LAW SCHOOL

YOR K U N I VERSITY

\section{OSGOODE HALL LAW SCHOOL}

Comparative Research in Law \& Political Economy

\author{
RESEARCH PAPER SERIES
}

Research Paper No. 14/2012

TBGI Project Subseries No. 2

\section{The Embededdness of Responsible Business \\ Practice: National Institutional Environments and \\ Corporate Social Responsibility}

\author{
Luc Fransen
}

\section{Editors:}

Peer Zumbansen (Osgoode Hall Law School, Toronto, Director, Comparative Research in Law and Political Economy)

John W. Cioffi (University of California at Riverside)

Leeanne Footman (Osgoode Hall Law School, Toronto, Production Editor)

\section{The TBGI Project}

Transnational initiatives to regulate business activities interact increasingly with each other and with official regulation, generating complex governance ensembles. Heterogeneous actors and institutions interact at multiple levels and in various ways, from mimicry and cooperation to competition and conflict. The TBGI Project investigates the forms, drivers, mechanisms, dynamics, outputs and impacts of transnational business governance interactions (TBGI) from diverse theoretical and methodological perspectives. It is funded by a Social Sciences and Humanities Research Council of Canada grant led by Professor Stepan Wood, Osgoode.

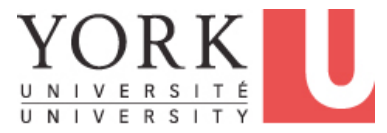




\begin{abstract}
:
Academic literature recognizes that firms in different countries deal with Corporate Social Responsibility (CSR) in different ways. Because of this, analysts presume that variations in national institutional arrangements affect CSR practices. Literature however lacks specificity in determining, first, what parts of national political economic configurations actually affect CSR practices; second, the precise aspects of CSR affected by national-institutional variables; third, how causal mechanisms between national institutional framework variables and aspects of CSR practices work. Because of this the literature is not able to address to what extent CSR practices are affected by either global or national policies, discourses and economic pressures; and to what extent CSR evolves as either an alternative to or an extension of national institutional arrangements. This paper proposes an alternative approach that focuses on an exploration of links between disaggregated variables, which can then be the basis for imagining new national-institutional configurations affecting aspects of CSR.
\end{abstract}

Key words: Corporate Social Responsibility; national institutions; political economy; varieties of capitalism; globalization

JEL Classification: F55 - International Institutional Arrangements; L38 - Public Policy ; P16 Political Economy; P51 - Comparative Analysis of Economic Systems 


\author{
Osgoode CLPE Research Paper 14/2012 \\ Vol. 08 No. 04 (2012) \\ Luc Fransen
}

\title{
The Embededdness of Responsible Business Practice: National Institutional Environments and Corporate Social Responsibility
}

\section{[A revised version of this working paper is forthcoming in Journal of Business Ethics]}

Corporate Social Responsibility (CSR) is the term that describes a firm's voluntary actions to mitigate and remedy social and environmental consequences of its operation. ${ }^{\mathrm{i}}$ It plays an increasingly significant role in public discourse on the governance of globalization, in particular as the transnational organization of production and, consequently, the disembedding of economic action from enforced public regulation has accelerated over the last decades (Marshall and MacDonald, 2010).

In the effort to explain why firms engage with CSR, and why they choose for particular types of CSR practices, the institutional environment of business plays a significant role (Campbell, 2006; Crouch, 2007; Matten and Moon, 2008). Many authors hold that as part of this environment, nationalinstitutional pressures are significant drivers to variations in corporate strategies towards CSR, and varying types of self-regulation and private regulation (Christopherson and Lillie, 2006; Kollman and Prakash, 2002; Matten and Moon, 2008; Lee, 2011). In recent years, this notion has spurred analyses of the relationship between varieties in national political-economic configurations and varieties in CSR practices.

This paper identifies important gaps in our understanding of the relationship between national political-economic configurations and CSR practices so far and develops proposals to help close these gaps. It will argue that the literature so far, lacks specificity in three important respects, as a 
cumulative result of the conceptual and methodological characteristics of studies. First, because of its predominant focus on aggregate measures of national configurations, the literature is not yet able to identify what particular aspects of national economic systems affect CSR practices. Second, because aggregations are also used for CSR as a dependent variable, the literature cannot yet clearly distinguish what aspects of CSR are precisely affected in what way by variation in national institutional environments. Third, the literature so far has difficulties in providing convincing demonstration of the causal mechanisms at work between national institutions and corporate strategies towards CSR.

Because of this, the literature so far is not able to successfully address what are arguably two key questions pertaining the relationship between CSR and the national institutional environment: first, to what extent CSR embodies a global diffusion of business norms and practices?; second, to what extent CSR embodies a change in the institutional framework for policies regulating and coordinating the social and environmental consequences of economic activities?

The paper then suggests revisions in how to treat these questions. As a first step, it proposes to comparatively and qualitatively focus on the relationship between particular aspects that are disaggregated from the big concepts 'CSR' and 'national political-economic configurations'. By doing so it seeks to establish causal links from bottom up, instead of from top-down. Working from the bottom up, means that inductively institutional ensembles can be identified that do not have to be restricted to common comparative political economy variables, but may include aspects of the organization of civil society, social movement dynamics and specific elements of government regulatory and distributive policy. In addition, such an approach may then more easily engage with academic debates that are organized around particular dimensions of CSR practice as a dependent 
variable, and which do not use an elaborate understanding of national political-economic configurations, such as studies of business engagement with certification, private labor regulation, sustainability reporting and environmental management systems. This means that a more integrated understanding of the national embeddedness of different kinds of responsible business behaviour, self-regulation and private regulation can emerge.

This paper does not intend to dismiss the work done so far on the national embeddedness of CSR practices. It aims to treat discussed studies as valuable social science contributions. Not all of the works discussed suffer from all vulnerabilities mentioned here. In most of these studies, the authors also recognize that there are limits to their analytical and empirical research strategies. The point of this paper, nonetheless, is that the cumulative effect of these separate takes is a set of significant gaps in our understanding. Future research should address these gaps seriously.

The paper is organized as follows. First the contributions of the literature on national varieties of CSR will be discussed. Then this literature will be scrutinized for its understanding of national political-economic configurations, Corporate Social Responsibility and the connections between the two. The section that follows draws out an alternative approach to the study of the national embeddedness of responsible business behaviour and illustrates this with two empirical examples. A final section concludes.

\section{The debate on the national embedding of CSR policies so far: substitution versus extension and the global versus the local}

Most introductory texts to Corporate Social Responsibility acknowledge that across countries, firms are embedded in different institutional settings. Firms in different countries face different regulatory frameworks, governments, societal stakeholders, have different relationships towards 
owners and engage in different types of industrial association and labor-capital bargaining. Such differences may affect how firms approach the debate on CSR (for instance Crane and Matten, 2005: 26-30; Van Tulder and Van der Zwart, 2006: 221-230). CSR as a term is of American origin, but has since the 1990s proliferated across the globe. The national differences in applying this American invention then have become a focus of empirical research.

Contemporary literature identifies a national political-economic context to CSR strategy by investigating the effect of national variation on selections of firms that occupy positions in corporate best practice rankings of CSR activities, issue sustainability reports or participate in CSR-focused business associations (Aguilera et al., 2006; Gjolberg, 2009; Jackson and Apostolakou, 2010; Kang and Moon, 2011; Kinderman, 2009, 2011; Maignan and Ralston, 2002; Midttun, et al. 2006; Steen Knudsen and Brown, 2011). These national varieties accordingly signify different versions of capitalism that vary with regard to such characteristics as industrial relations, corporate governance, inter-firm relations and state intervention in the economy.

On such basis, the literature offers two rival claims concerning the relationship between national institutions and aspects of CSR. The first is that firms from countries that approximate the Coordinated Market Economy (CME) or Rhenish and Nordic models of capitalism (Soskice and Hall, 2001; compare Albert, 1991; Amable, 2003) will develop more extensive CSR practices in comparison to firms from other countries. Nordic, Rhenish and CME-approximating countries are characterized amongst others by institutionalized dialogue between social partners and more stringent rules in policy areas relevant to CSR, such as labour standards and environmental protection. Such institutions make it easier for firms in these countries to comply with international CSR programs and rating schemes, since what is legally required already makes them frontrunners in comparison to 
firms from other countries (Gjolberg, 2009; Midttun et al., 2006). In addition, these institutions also make companies more susceptible for new types of voluntary engagement in which to continue engagement with stakeholder groups and their concerns (Campbell, 2007).

The rival claim is that countries approximating the Liberal Market Economy (LME) or Anglophone model have more extensive CSR practices. These countries are characterized amongst others by a less interventionist state, individualized and adversarial capital-labour relations and liberal markets for corporate control. Demands for solidarity and regulatory activities are taken up through private instead of public routes. CSR activities then compensate for the absence of institutional solidarity and stringent public regulation (Jackson and Apostolakou, 2010). In line with literature that identifies institutional changes in the political-economic configuration of Continental Europe as a move towards a Liberal Market and Anglophone model (Nölke, 2008), Daniel Kinderman (2009, 2011) furthermore proposes that CSR may be on the rise in Continental Europe precisely because conventional forms of capital-labour interaction and state intervention are in retreat there. CSR then functions as legitimation of liberal markets in the United States and the United Kingdom and as legitimation of a process of marketization elsewhere.

These rival claims find support mainly in large-N empirical analysis using inferential statistics or Qualitative Comparative Analysis (QCA). The data used for exploration of qualities of CSR are corporate policy documents and public rankings based on such documents. Hypotheses used for the large-N analyses are mostly based on deductive reasoning or smaller case studies comparing corporate policy documents (see for instance Campbell, 2007; Maignan and Ralston, 2002; Steen Knudsen and Brown, 2011).

Most of these studies in addition consider other factors that may drive variation in CSR practices. These include amongst others differences between industrial sectors (Jackson and 
Apostolakou, 2010) and political culture (Gjolberg, 2009). Alternatively, studies emphasize how degrees of internationalization and presence of multinational corporations may affect CSR practices in a country. By doing so, they open up a second analytical debate, as to the source of variation in CSR practices across countries: do we have variation in national versions of CSR because of global forces and the position of countries in the global economy, or because of the effect of local institutional environments? Gjolberg (2009) in this regard finds that both local institutions and global connectedness may drive more or less extensive CSR practices, although possibly in different ways (compare Steen Knudsen and Brown, 2011).

Overall, at the heart of the argument, is the interaction between national political-economic configurations on the one hand and measures of CSR that express degrees of extensiveness, comprehensiveness, progressiveness and advancement. And with regard to both the prevalent mechanism and the direction of causality we are at present left with puzzles: do more coordinative or more liberal types of national political-economic configurations advance extensive CSR practices? Or do both configurations promote CSR at specific times (Kang and Moon, 2011)? And is CSR developed due to global pressures, local pressures or both?

In the next sections, these contributions will be scrutinized.

\section{What we do not yet know about the national embeddedness of CSR}

The present literature has three limits. Based on what we have learned so far we remain predominantly uncertain about what aspects of national institutional frameworks of business actually affect CSR practices, self-regulation and private regulation; about what aspects of CSR practices are affected; and how the causal mechanisms between the two phenomena work. These limits constrain 
efforts at convincingly solving the puzzles in the literature identified in previous section. In the sections below, these three different elements will be discussed in turn.

\section{1 What parts of the national institutional environment affect CSR practices?}

Most studies of the national embeddedness of CSR practices base their hypotheses on comparative political economy literature that establishes variation in national business systems, or, versions of capitalism with regard to corporate finance and governance, inter-firm relations, capital-labour relations, education and training (Soskice and Hall, 2001), and state institutions and policy, financial systems and trust relations (compare Amable, 2003; Becker, 2008; Whitley, 1999). This is a sensible starting point, since this literature provides ample inspiration for theorizing on the embedding of economic practice in national configurations. However, connecting "comparative capitalism" (Jackson and Deeg, 2008) to the study of CSR practices is not without its problems. This section in particular discusses the usage of imprecise empirical results for specified theoretical arguments; the sustaining of analytical problems of the Varieties of Capitalism-approach to comparing national configurations; and the relative disregard of elements of political-economic configurations not treated in the comparative capitalism literature.

The studies on national embeddedness of CSR so far provide arguments focusing on the replacement versus extension of certain features of the national environment by CSR practices, selfregulation or private regulation. These features include social or environmental government policy, corporate governance and capital-labour relations. In line with the notion of the complementarity of institutions, some of these arguments state that CSR practices have a particular position with regard to the combined functioning of these institutions. However, many studies use aggregate measures of varieties across national versions of capitalisms, rather than focusing on specific elements, or the 
combination of elements that may affect CSR practices. Measures used include countries as units of analysis reflecting typical versions of capitalism, or tax rates and investment laws which are proxies for the elaborateness or the regulatory character of the (welfare) state (Kinderman, 2009; Jackson and Apostolakou, 2010). The likely relationship between national political-economic configurations and CSR practices are thus relatively specifically theorized. But national institutions are not always sufficiently operationalized to show the proposed relationship empirically at work (for an exception see Gjolberg, 2009). We should therefore be careful about not creating a mismatch between the specificity of data and the level of generality of the theory used.

The most cited study that compares national versions of capitalism is the Varieties of Capitalism (VoC) volume by David Soskice and Peter Hall (2001). It is therefore the most likely source of emulation by scholars investigating national variety in CSR (see for instance Jackson and Apostolakou, 2010; Kang and Moon, 2011; Midttun et al., 2006). Studies may use Soskice and Hall's distinction between LMEs and CMEs in selecting and analyzing cases of national-institutional variety. Alternatively they may include an extra ideal type of Because of this, studies of CSR practices are also in danger of inheriting and sustaining some of the shortcomings of the VoCapproach that have been outlined in recent years (Becker, 2008; Crouch, 2005; Jackson and Deeg, 2008).

The main criticism concerns its static depiction of political-economic institutions in temporal and geographic terms. Because of its insistence that national institutional variation will prevail in times of globalization, the VoC-approach is a difficult starting ground to theorize national institutional change. And because CSR practices may embody or advance such change, the fit with regard to the debate on the national embeddedness of CSR is in particular problematic (see also 
Kinderman, 2009). Much of this stasis is related to the fact that VoC-analysts conflate country cases with national capitalist ideal types, instead of constructing ideal types of capitalist diversity and describing national cases as more or less approximating such ideal types, based on empirical research. This does not only mean that institutional change becomes difficult to describe, it also creates the problem of identifying country cases that are empirically in between the LME and CME, or in between LME and CME and the newly proposed State Led Market Economy (SLME) models in terms of their institutional characteristics (Kang and Moon, 2011). The study of national embeddedness of CSR then is in danger of falling prey to the crude dichotomy of two or three models, in both case selection and causal inference. Or, alternatively, treating changes in a country as changes in a model, rather than deviation from it. Finally, critics lament that the selection of key factors that make up the categories of Varieties of Capitalism are not sufficient to describe the appropriate variation; most of all, approaches adopting $\mathrm{VoC}$ are in danger of missing out on variation in state policy. This may be an important variable affecting CSR policy.

In establishing variations among countries, comparative capitalist research assumes the importance of the interplay of different kinds of national institutions. These ensembles have so far predominantly been used in the literature to explain national indicators of economic performance. Jackson and Deeg (2008, p. 683) for instance summarize the literature's interest in the effects of national complementarity of national institutions on innovation, production strategies and distributional outcomes.

As said, the ensembles of institutions identified in this literature are also used to explain variation in CSR policies. The explanatory value of these particular ensembles as representative of variation within national economic systems for CSR issues is however not self-evident. To be sure, the relationship between the processes that drive national varieties in innovation, production and 
distribution on the one hand and CSR on the other are worth exploring. There is a connection between these indicators of economic performance and the kind of things that firms do with regard to their ethical agenda. CSR is after all about managing negative externalities of mostly production and for many industries CSR concerns may be solved by way of innovation, in particular with regard to energy and waste.

But it is questionable whether we should prioritize specifically these ensembles in an investigation of CSR. CSR, after all, so far is not integral to economic innovation, production and different types of economic distribution, at least not organizationally speaking. Studies show that CSR strategies too often lead a marginalized existence in the corporate organization (Mamic, 2004; Crane, 2000). We should therefore take into account that different political-economic national institutions may affect CSR. Literature on the emergence and adoption of specific CSR practices for instance points us to the role that consumers, NGOs and discourses on sustainability play (Micheletti,2003; Sasser et al., 2006). The power and significance of these factors are of course also affected by the character and quality of other national political-economic institutions. In other words, concentrating on $\mathrm{VoC}$ and broader comparative capitalism-literature may result in neglect of those variables not inherent in the comparative capitalisms-models, which may however play a significant role in explaining national variation with regard to CSR issues. And institutions that establish certain results in one sphere of business activity, should therefore not be too hastily considered to also have the most significant effect in other spheres. ${ }^{\text {ii }}$

\section{2 What part of CSR is affected by national institutional environments?}


This section will argue that because recent studies of the national embeddedness of CSR use aggregate conceptions of CSR as a dependent variable, much remains unclear about what aspects of CSR practices are actually affected by national political-economic configurations. This is because of the conflation of different aspects of policy-making, unclear division of geographic scope, and lack of preciseness with regard to corporate engagement with different CSR issue areas.

Most studies so far gauge CSR practices based on (a combination of) the following data: first, corporate policy document analysis; second, data sets from existing CSR ranking tools which are based on corporate policy document analysis; third, corporate participation in business associations geared towards CSR goals; fourth, corporate participation in certification programs and private regulatory organizations.

Jackson and Apostolakou (2010) for instance analyze companies participating in the Dow Jones Sustainability Index. Gjolberg (2009) uses a mixed weighing of membership in business associations, environmental process management certification with sustainability indexes and business toplists. The obvious disadvantage of such indicators is that the population of companies analyzed is likely to be leaning towards larger, stock-listed organizations. But we could argue that as a first step into the analysis of national institutions and their effects on CSR practices we are interested in the "big fish", because of their prominent place in debates about fair globalization and their possible impact on social and environmental issues.

Most of the studies take the pragmatic approach to defining what is meant by CSR: the authors leave it to the indicators developed by businesses, analysts and stakeholders to determine what falls in and outside of the scope of the concept, in terms of both policy tools and issues. We might however also be interested to disaggregate some of the aspects of CSR practices because of the different political and managerial implications they have. The classic distinction in analyzing 
voluntary responsible business behaviour in the business ethics literature is for instance between Corporate Social Responsibility (signifying a corporation's stated obligations and accountability to society), Responsiveness (the activities that follow from this) and Performance (the results of these activities, for discussion see Crane and Matten, 2005: 41-49). The measure of "CSR practices" used in the literature on the national embedding of CSR tends to conflate the first two. This means that based on current research we do not know to what extent national variation in political-economic configuration affects the scope of obligations taken on by firms, and to what extent it affects the precise activities that are developed to put these obligations into practice.

If we use more specific distinctions, inspired by policy-making literature (see for instance Parsons, 1995) we can identify seven relevant dimensions of corporate engagement with CSR in a country: quality of standards adopted (for instance specificity and elaborateness of standards with regard to working conditions, environmental damage); policies adopted to implement and monitor these standards (in terms of elaborateness, stringency, etc.); scope of policies (governing the corporate organization, the whole or parts of the supply chain, with a national, regional or global reach); issues addressed (environmental, social, human rights-related, etc.); quality of reporting on performance (in terms of elaborateness and transparency); degree of outside verification of results (indicated by membership in associations, voluntary programs, certification schemes) and scope of uptake of policies (by only a few or by a majority of industry in a given country).

All dimensions have something significant to say about the quality of a country's corporate efforts towards CSR. Yet these dimensions may in different ways be related to national institutional environments. The present literature either uses yardsticks of CSR that mix these different elements together, or uses one of the aspects identified above as a proxy for quality of CSR as a whole. The 
former may result in imprecise measurement of relationships between national environments and CSR practices. The latter may result in unspecific statements about the variation identified.

Gjolberg's work (2009) is an example of a mixed measurement of CSR practices. On the basis of her work we see that firms from Nordic countries may be more amenable to apply high standards and/or report transparently on performance and/or have their performance reviewed by third parties and/or apply CSR across the supply chain, and so on. Meanwhile, the degree of a firm's engagement with transparent reporting, stringent standards of behaviour and responsibility with supplier companies all may interact in different ways with different aspects of Nordic political economic institutions. What is for instance common practice regarding non-CSR business reporting requirements might have some impact on CSR reporting practices, as one specific element of CSR practices. It may however affect other elements to a lesser degree, such as the degree to which Nordic companies join programs that verify their commitment to CSR standards in supply chains.

Kinderman's work (2009) is an example of a study using a singular proxy for CSR practices. It argues for a "substitute" effect of CSR and national regulation. while in effect it measures national variation in business propensity to organize in CSR-focused business associations. But, rather than an integral aspect of CSR, this willingness of firms to organize on CSR may be hypothesized to be an effect of national variation in patterns of industrial association, or, put simply, national variation in firms' willingness to act collectively in the first place, as Kinderman himself recognizes. The relationship with the argument on substitution of conventional forms of social and environmental bargaining and regulation is therefore not yet clear. As was established in the previous section, we do not know whether this element was the most important driver to variation, since aggregate variables of national institutions were used to study variety across countries. The proxy furthermore does not tell us about national variation in what business associations demand from their members in terms of 
commitment to standards, performance, reporting and so on. This variation in itself may be relevant for identifying national variation in CSR practices. If the French national association is more lenient in terms of required participant commitment in comparison to the Belgian one, we may actually be measuring a difference in preference due to variation in stringency of CSR standards, rather than differences that can be explained through national institutional variety (Prakash and Potoski, 2007).

Furthermore, the measurements of CSR used do not distinguish between business practices addressing CSR issues at home or abroad (for discussion see also Steen Knudsen and Brown, 2011). This is a significant distinction since we may easily expect a close interaction between nationally focused business policies and existing elements of a national political-economic configuration identified in these studies, tailored to issues belonging to the CSR agenda. This interaction may then lead us to hypothesize about the "mirroring" or "substituting" relationship between national institutional frameworks and CSR practices. Policies with regard to anti-discrimination or waste management at home may for instance be attuned to national discussions, routines and regulations with regard to these issues. For issues that relate to business activities abroad, through export, import or Foreign Direct Investment channels, the relationship between the national political-economic configuration as identified so far by these studies and CSR practices is probably less clear-cut.

Similarly, the measurements of CSR used in the literature so far do not disentangle the extent of business commitment to social or environmental or broader human rights standards. This while their theories propose interactions between CSR practices and national institutions that may be more suited for some of these categories of standards than for others. For instance, the theses on mirroring or substituting of national institutional environments work really well with regard to the issue of social standards. There, conventional corporatist arrangements structuring interactions between 
representatives of labour and capital may spill over into or be traded off for CSR stakeholder dialogue arrangements. With regard to environmental and human rights standards, different regulatory constellations interact with CSR. The link with corporatism is much less clear-cut here, since these issues do not conventionally form part of corporatist institutional interaction. Using aggregate measures of CSR, it remains uncertain how these different constellations may affect business engagement with these issues. And theories deduced from corporatism studies seem to make less sense in approaching the non-labour aspects of the CSR agenda.

\subsection{How do the national institutional environment and CSR affect each other?}

As we have seen, the study of national determinants of CSR strategies has led to a controversy regarding the impact of national institutions on corporate activities. It is undecided whether certain institutional features such as strength of corporatist tradition foster or hamper corporate engagement with CSR. It could very well be that this controversy stems from usage of different indicators of CSR practices, as discussed above. This would mean that the substitution thesis could hold for a specific element of CSR practices, while the extension argument holds for a different one. Alternatively, it may be that different populations of organizations have been sampled in the studies discussed. In this case, the common advice in methodological literature is to increase the amount of observations to more clearly establish empirical patterns and derive appropriate conclusions (King et al., 1994).

Previous sections have shown that there may be ground to base these new observations on alternative operationalizations of the key variables, an issue that we return to below. Meanwhile, we may also wonder whether the data and methods used so far allow us to illuminate the causal mechanisms we are looking for. In terms of the data, the analysis relies mostly on corporate selfpresentation and rankings of self-presentation by third parties. This means that the analysis is based 
on comparison of static snapshots. Using these data sources has obvious advantages in terms of the availability and reliability of data. Most of the reports on which analyses are based can be freely reviewed by researchers. The drawback in terms of our understanding of the national embeddedness of CSR is that studies hardly provide data on the process of strategizing within firms and the observable interactions between components of the national institutional framework and business activities. $^{\text {iii }}$

A second drawback is that most data used do not allow us to distinguish between on the one hand CSR practices, self-regulation or private regulatory participation that follows from legal requirements and on the other practices that may be driven by other kinds of national-institutional pressures. This is obviously an interesting distinction to pull apart if we consider that, first, most definitions of CSR stress the voluntary nature of business engagement with social and environmental standards. Is CSR through legal requirements then still CSR? Second, our interest in the relationship between national political economic-configurations and CSR require us to specify the character of the relationship between the two as best as possible. We should therefore be clear about what we are measuring in order to grasp the mechanism at work. Ideally, we therefore need to work with data that separate different types of interactions between CSR practices and national institutions.

In terms of method, most studies apply QCA or inferential statistics to large case selections of firms or industries in countries (for an exception using a few exemplary case studies, see Kinderman, 2009; Steen Knudsen and Brown, 2011). While some would hold that such large-N methods are sufficient to demonstrate the functioning of a causal mechanism, social science methodologists stress two requirements for successful identification of a mechanism: first, the existence of a general model explaining a wide variety of outcomes; and second, observation of a process running from a cause to 
an effect we are interested in (Gerring, 2001; Marini and Singer, 1987). Through its rooting in comparative political economy, the literature can amply provide the former, but it currently scarcely provides the latter. ${ }^{\text {iv }}$

While one may have issues with the methodological position as generally advanced here, it is clear that with regard to the theoretical debate on CSR and national institutions, analyses so far lead to ambiguous conclusions. We are uncertain about both the direction of causality and whether the assumed independent variable stands in a positive or negative relationship to the assumed dependent variable. We may at least conclude from this that adding alternative methods to those presently applied will be useful. Not only extended application, but diversification of both methods and data may help to overcome the puzzle that the present literature leaves us.

\section{An alternative line of research}

We have so far established that in order to learn about the interaction between national politicaleconomic configurations and CSR practices, we run into limits if we rely on aggregate measures of both, and on large-N methods with static snapshot data to establish their interaction. Below, an alternative direction for research will be outlined, focusing on the disaggregation of concepts, process tracing, induction and openness towards other literatures. This route may complement the research done so far and increase our understanding of the national embeddedness of CSR. By advocating such direction, this paper basically chimes in with those comparative political economy approaches that promote an inductive, empirically informed construction of concepts and typologies across country cases, and sensitivity to complexity in order to study national diversity and institutional change in modern-day capitalism (Amable, 2003; Becker, 2008; Crouch, 2005). After introducing the 
approach, two empirical examples illustrate how it may be applied in order to benefit our understanding of CSR practices.

\subsection{From disaggregation to new ensembles?}

The first way to advance the study of the national embeddedness of CSR is to use smaller and more specific measures of both national political-economic configurations and CSR practices. The empirical focus of the study can then be specified depending on an interest in particular aspects of a national-institutional environment as an independent variable, or particular CSR practices as a dependent variable.

Starting with the former, theories so far assume a relationship between for instance stricter environmental regulation, generous welfare policies and well-established corporatist arrangements on the one hand and CSR practices on the other. Studies can then use measures of these variables and probe their effects (see for instance Gjolberg, 2009b). Moreover, particular CSR practices can be identified that may to a greater or smaller degree be affected by such variables. We may select several, including particular issue fields, the participation of firms in organizations monitoring actions in supply chains, quality of reporting, and so on. We can then see more clearly whether there is a relationship with particular aspects of a national political-economic configuration of interest to us and establish how the two may affect each other.

If we are principally interested in particularly CSR practices and want to learn how national embeddedness affects them, we can conversely select for those aspects. Theoretically we may for instance expect that there is a national embedded character to CSR reporting by firms or the emergence of business-NGO collaborations with regard to certifying social and environmental 
requirements of production. We may then study which parts of the national-institutional environment affect such practices. Important here is that the factors of possible influence may extend the categories identified by the comparative capitalism-literature. This means that care should be taken to identify appropriate categories of variations.

Methodologically, it is therefore crucial that the research design is sensitive to inductive reasoning. This would mean, first, that smaller qualitative case study set-ups would be most appropriate in the first phase of investigation. Second, in line with the notion that for the establishment of causal mechanisms we need both a general theoretical framework and an idea of how the relationship between cause and effect empirically functions, it is important to apply process tracing (for discussion see George and Bennett, 2004). This means that empirical information needs to be gathered that establishes as precisely as possible the interactions between variables, ideally across time and space.

In terms of data, this implies a focus on interview data with representatives of firms and those organizations surrounding them, in combination with policy document analysis, potentially participant observation during professional gatherings, and socio-economic statistics concerning firms, sectors and countries.

Such advice may cause some researchers to lament the implicit preference contained in using qualitative case study designs and closer-to-date source-research methods. Indeed, there are strong advantages to using these in the first phases. But, importantly, there is no objection to using the results of such studies for larger QCA and inferential-statistical purposes.

The advantage of such a set-up is that it, first, becomes possible to confirm or refute assumptions about the effect that different national institutional environments have on particular aspects of CSR strategies and policies. Second, it may, based on results, be possible to propose 
different ensembles of national institutions that affect CSR policies than the ones currently identified. Accordingly, different kinds of institutional complementarity of CSR practices can be described. These can then be tested for a larger population of cases using inferential statistics or QCA.

Finding possible new variables that may be included in such ensembles does not have to be a chance-encounter affair. Using disaggregated measures of CSR practices and national political economic configurations has as an advantage that we can more easily relate to literature that describes specific aspects of these concepts but has so far remained outside or at the margin of discussions in the discussed studies of the national embeddedness of CSR.

With regard to national political-economic configurations we can build on literature that comparatively describes institutional features plausibly relevant to CSR practices. The literature on government policies focusing on CSR provides a lot of clues on what kinds of pressures may be exercised on industries in different countries (Albareda et al., 2007; Knopf et al., 2011; Steuer, 2010). We can also think of comparative studies probing government external economic policy, such as trade agreements or aid policies, which may intertwine with the international scope of CSR practices. Similarly, comparative studies of consumer attitudes may go some way in providing information on differences across countries (Lee et al., 2011; Clarke, 2003). And strength of organization of civil society groups can also be gauged for different countries (Kriesi et al., 1992).

With regard to different CSR practices, we can build on studies that aim to shed light on specific aspects of CSR, and which then in the process develop causal inferences regarding nationalinstitutional variables. Work on environmental management systems for instance shows the positive influence that practical government and business association assistance has on adoption of environmental requirements by companies (Kollman and Prakash, 2002). In a similar vein, studies 
show the significance of government procurement in advancing certain models of sustainability certification (Overdevest, 2010; Zeitlin, 2011). And others propose that national variation in discourses and practices of consumer sovereignty and experiences with accounting standards may explain differences in business preferences for organizing multi-stakeholder initiatives and reporting on CSR performance (Hughes et al., 2007).

Such a set-up may thus facilitate theoretical openness, because it eases integration of other perspectives on corporate behaviour outside of the realm of the academic sub-discipline of Comparative Political Economy. Using the proposed set-up, it will become easier to build links with approaches favoring other independent institutional variables for corporate action, that stem from other academic traditions, such as policy studies, organization theory, social movement research, and economic geography. Similarly, it facilitates integration with dependent-variable focused studies of CSR strategies that already take into account national determinants of corporate action.

Below, two examples are given of how such an approach may function with regard to the empirical analysis of specific and pertinent aspects of CSR practices, self-regulation and private regulation. The first example is a forward-looking hypothesis building exercise, taking a particular aspect of a national political economic configuration underspecified in the current literature and elaborating on its significance for CSR practices. The second example applies backward-looking hypothesis building, taking a specific aspect of CSR practices and relating it to different aspects of a national political economic configuration (Scharpf, 1997, pp. 22-27). Both cases show we can hypothesize about new ensembles of national institutions affecting CSR and thereby create more insight into the debate on the global or local dimension of CSR and its substituting or extending quality vis à vis national institutions. 


\section{2 Empirical illustration I: CSR, development policy and the "global-local-debate"}

Governmental development agencies and development ministries are in many ways involved with the development of CSR practices in several countries. Academic literature shows that especially in Western Europe, agencies and ministries have been involved in bringing together businesses, unions and NGOs to facilitate voluntary business activities with a human rights, social and environmental dimension. This includes organization of practical learning and exchange fora to privately improve global labor conditions (see for Germany, Hiss, 2004); efforts to finance the development of specific multi-stakeholder organizations that regulate labor standards across borders (see for the United Kingdom, Hughes et al., 2007; for Norway, see Brinkmann, 2004); to assist in capacity building in order to improve the regulation of sustainability standards (for Germany, see Fransen, 2011; compare Cashore et al., 2006) and to enhance harmonization of existing competing private certification standards for sustainable production (for the Netherlands and Germany, see Kolk, 2011).

Governmental development policies therefore help shape CSR practices that have an international scope and relate to the sustainable development agenda. These practices include particular CSR instruments, organizations, business strategies and the interactions between businesses and stakeholder groups. It is worthwhile to examine governmental development policy effect on variations in CSR practices across countries. Do development agencies and ministries of different countries perhaps deal with CSR practices differently? And if so, what variation between development policies across countries may help explain different treatments of CSR?

It may, first, be that there is a variation in engagement with CSR practices that corresponds with the relative size of the development aid budget. Countries spending more on development aid 
may then affect national CSR practices more than those that spend less. Second, variation may occur because of variations in substantial focus of the policies. For instance more or less predominant political ideologies may affect views on what constitutes appropriate development aid. Especially the predominance of liberalism in shaping governmental policy may to a higher or lower degree encourage market-driven perspectives on sustainable development, which may put the contribution of companies in donor and recipient countries centre stage in governmental development policy (for a discussion of marketized development aid, see Koch et al., 2007). Similarly, academic literature recognizes variation in the degree to which development aid is shaped by either national self-interest, concern about human suffering or performance conditions for recipient governments with regard to for instance human rights (Alesina and Dollar, 2000; Neumayer, 2003). Such variation may also affect development policies involving CSR, and thereby CSR practices.

These variations across countries of course do not stem from the influence of development policy alone. The shape of governmental development policy towards CSR probably co-evolves and interacts with other national-institutional factors. We can identify an ensemble of the following institutional factors. The relative "idealism" driving development assistance may mirror the degree of emphasis on global justice issues in a government's foreign policy (for the example of Sweden, see Gjolberg, 2010); the presence or absence of multinational corporations with activities in developing countries, may or may not stimulate public-private debate on sustainable development in a country; governmental development budget may also be invested in projects of developmental NGOs, some of which may use part of their resources to develop awareness campaigns on human rights, labor standards and the environment that go on to target national industries; and the relative openness of the economy to trade flows may encourage a particular outlook on social and environmental problems among political organizations. 
From this we can inductively build an ensemble of national institutions that in combination address global issues, see Figure One. CSR practices with an international scope probably belong to such an ensemble, but are for analytical purposes depicted as separate yet interrelated.

[Figure 1 here]

Such ensemble speaks directly to the discussion of whether CSR practices are shaped by global or national variables. National-institutional ensembles, instead of merely being affected by global forces, also directly shape economic globalization in terms of trade, the organization of production and financial flows. The CSR practices that deal with the externalities of global economic activity similarly may co-variate. In other words, a country's position in the world economy and the way its domestic institutions manage globalization may affect CSR practices of businesses in that country. Differences in such positions and the management of globalization may stimulate differences in CSR practices. Such a hypothesis transcends the global-local distinction identified in the literature on the national embeddedness of CSR.

\section{3 Empirical illustration II: CSR, environmental conservation and the "substitution-extension"-} debate

Environmental conservation is a central concern of many CSR practices, given how many business processes may negatively affect the balance in ecosystems. Conservation furthermore also dovetails with concerns about CO2-reduction. Within the literature on environmental politics, it has been hypothesized that the growth of voluntary business practices that deal with environmental 
practices may constitute a privatization of environmental governance: a move away from public regulation of environmental practice and towards set-ups in which industry actors predominate (Clapp, 1998; Lane, 2003). The studies refer to different aspects of CSR practices that may be a manifestation of this privatization. These include adoption of generic systems by businesses to manage negative environmental externalities. Another example is the participation of industry players in the certification of forestry and fisheries, in both rule-making and rule-taking roles. This is then in line with the substitution-hypothesis posed in the literature on the national embeddedness of CSR.

This literature at the same time however shows that the extension-hypothesis to CSR embeddedness has value. With regard to the certification of forestry practices, the lead in terms of business participation in certification schemes has been taken by industries from developed countries, in particular those with already more elaborate environmental regulation (Auld et al., 2008: 192-197), including Northern European and Northern American governments. The literature holds that variation in business uptake of this kind of voluntary environmental practice may indeed depend on variables familiar to the comparative capitalist-literature, such as degree of industrial association and government intervention. But other national factors less familiar to this literature may also affect business strategy, such as a country's trade dependence and the pressure tactics and strength of environmental NGOs. Finally, the degree to which conservable nature is present within a country's borders obviously also matters (compare Sasser et al., 2006; Overdevest and Rickenbach 2006).

A third perspective in the environmental politics literature emphasizes the increased interaction between public and private institutions in the making of environmental policy. It focuses for instance on the role of governments as procurers of products that are privately certified, as managers of nature using voluntary business management systems, and as facilitators of new private environmental certification programs. What is more, literature shows that private policies inspire new 
or revised government regulation of environmental issues. Alternatively, privately set standards become embedded in national policies which set formal legal requirements to industry parties (for discussion see Gulbrandsen, 2011; compare Gale and Haward, 2011; Zeitlin, 2011). This literature then opposes the simple privatization thesis and replaces it with more complex notions of publicprivate or hybrid governance. The evolution of the relationship between voluntary CSR practices and government policy, and its effects, are thus investigated without prior assumptions about the one dominating or crowding out the other.

Also here, we can construct an ensemble of national institutions whose variation across countries may help to explain variation in CSR practices, in particular with regard to adoption of environmental management and sustainability certification, see Figure Two. But it is important to emphasize the two-way interactive character of relationships between these practices and particular national institutions.

[Figure Two here]

This figure speaks to the discussion of CSR practices as an extension to or a substitution of national policies. It shows that there is interaction between both sets of variables and that next to substitution and extension also forms of hybridization can take place, which may affect our appreciation of the national embeddedness of CSR practices when aggregated over different issue arenas.

\section{Conclusion}


This paper has argued that the literature on the national embeddedness of CSR is so far not able to show how national institutional environments affects CSR practices. It demonstrates that a lack of specificity in measuring both CSR practices and national political-economic configurations, and larger-N leaning analyses based on documentation offering static policy information can only do so much to enlighten us regarding the relationship between CSR practices and national institutions. Table One summarizes key gaps in our understanding and the proposals to help fill these gaps.

[Table One here]

This paper therefore promotes empirical analyses of the national embeddedness of CSR practices that disaggregate both measures of national institutions and CSR practices. Such studies would use inductive reasoning and process-tracing with multiple data sources and closer-to-data methods in the first phase of the research design. Through such efforts, new ensembles of institutions affecting CSR practices can be proposed and tested, and integration of academic perspectives on CSR practices can be facilitated. The paper elaborates on examples of what such research projects may look like but countless other examples may be envisioned. Such efforts may more specifically hypothesize on mechanisms between aspects of national political economic configurations and elements of CSR practices. Moreover, studies may develop ideas about the scope conditions of such mechanisms, establishing for which national institutions and which aspect of CSR practices mechanisms may be more or less likely to work in the expected manner.

Once again, it is important to stress that this research strategy is expected to aid further research in the sense of enriching the cumulative level of research output by the community of scholars interested in the national embeddedness of CSR. This is not an argument against specific 
scholars that concentrate exclusively on large $\mathrm{N}$-analyses, or on static snapshot data. Rather, the idea is that these scholars in their research would use the propositions from process-focuses analyses as a starting ground, encouraging optimal cross-fertilization between research efforts and their individual results.

In this way, more convincing answers can be formulated regarding the questions of how global and national forces coincide in the shaping of CSR practices; and whether CSR practices stand in an extending or substituting relation to existing arrangements regarding social and environmental policy, and institutionalized labor-capital bargaining. In particular, this research agenda may inform discussion of, first, more or less beneficial interactions between public and private institutions, and second, the possible limits to a spread of CSR practices in geographic terms. Answers to these questions can then inform the debate on what role CSR can realistically be expected to play in governing the global economy.

\section{Notes}

i This description paraphrases the European Commission's definition of CSR, which is: "a concept whereby companies integrate social and environmental concerns in their business operations and in their interaction with their stakeholders on a voluntary basis." See http://ec.europa.eu/enterprise/policies/sustainable-business/corporate-social-

responsibility/index_en.htm, accessed April 152011.

ii Gjolberg (2009) remedies this by also looking at general proxies for amongst others political culture.

iii Witt and Redding (2011) perform interviews with business representatives to gauge CSR across countries, but their questions focus on respondent's values and preferences, not on strategic processes. 
iv We share this point with Kang and Moon (2011, p. 4) who offer an interesting analysis of developments with regard to variation across countries of corporate governance models and CSR. However, their analysis is based on discussion of developments in both, using secondary analysis, rather than empirically revealing the connections between both.

\section{References}

Aguilera, R. V., C. A. Williams, J. M. Conley., and E. D. Rupp: 2006, 'Corporate Governance and Social Responsibility: A Comparative Analysis of the UK and the US', Corporate Governance: An International Review 14(3), 147-158.

Albareda, L., J. M. Lozano, and T. Ysa: 2007, 'Public Policies on Corporate Social Responsibility: The Role of Governments in Europe', Journal of Business Ethics 74(4), 391-407.

Alesina, A. and D. Dollar: 2000, 'Who Gives Foreign Aid to Whom and Why?', Journal of Economic Growth 5(1), 33-63.

Amable, B.: 2003, The Diversity of Modern Capitalism, (Oxford: Oxford University Press).

Auld, G., L. Gulbrandsen and C. McDermott: 2008, 'Certification Schemes and the Impact on Forests and Forestry', Annual Review of Environment and Resources 33, 187-211.

Becker, U.: 2008, Open Varieties of Capitalism: Continuity, Change and Performances, (London: Palgrave).

Brinkmann, J.: 2004, 'Looking at Consumer Behaviour in a Moral Perspective', Journal of Business Ethics 51, 129-141.

Campbell, J. L.: 2006, 'Institutional Analysis and the Paradox of Corporate Social Responsibility', American Behavorial Scientist 49, 925-938.

Campbell, J. L.: 2007, 'Why Would Corporations Behave in Responsible Ways? An Institutional Theory of Corporate Social Responsibility', Academy of Management Review 32(3), 946-967.

Cashore, B., F. Gale, E. Meidinger and D. Newsom: 2006, 'Confronting Sustainability: Forest Certification in Developing and Transitioning Countries', Yale School of Forestry and Environmental Studies.

Clapp, J.: 1998, 'The Privatization of Global Environmental Governance: ISO14000 And The Developing World', Global Governance 4(3), 295-316. 
Christopherson S., and N. Lillie: 2005, 'Neither Global nor Standard: Corporate Strategies in the New Era of Labor Standards', Environment and Planning 37:11, 1919-1938.

Clarke, N.: 2008, 'From Ethical Consumerism to Political Consumption', Geography Compass 2(6), 1870-1884.

Crane, A.: 2000, ‘Corporate Greening as Amoralization', Organization Studies 21, 673-686.

Crane, A., and D. Matten: 2005, Business Ethics, (Oxford: Oxford University Press).

Crouch, C.: 2005, ‘Models of Capitalism', New Political Economy 10(4), 439-456.

Crouch, C.: 2006, 'Modelling The Firm in its Market and Organizational Environment: Methodologies for Studying Corporate Social Responsibility', Organization Studies 27(10), 15331551.

Fransen, L.: 2011, Corporate Social Responsibility and Global Labor Standards: Firms and Activists in the Making of Private Regulation, (New York: Routledge).

Gale, F. and Haward, M.: 2011, Global Commodity Governance: State Responses to Sustainable Forest and Fisheries Certification (New York: Palgrave Macmillan).

George, A. L. and A. Bennett: 2004, Case Studies and Theory Development in the Social Sciences, (Cambridge, MA: MIT Press).

Gerring, J.: 2001, Social Science Methodology: A Criterial Framework, (Cambridge, UK: Cambridge University Press).

Gjolberg, M.: 2009a, 'Measuring the Immeasurable? Constructing an Index of CSR Practices and CSR Performance in 20 Countries', Scandinavian Journal of Management 25(1), 10-22.

Gjolberg, M.: 2009b, 'The Origin of Corporate Social Responsibility: Global Forces or National Legacies?' Socio-Economic Review 7, 605-637.

Gjolberg, M.: 2010, 'Varieties of Corporate Social Responsibility (CSR): CSR Meets the Nordic Model', Regulation and Governance 4, 203-229.

Gulbrandsen, L.: 2011, 'Private and Public Governance Interactions: State Influences in Forest and Fisheries Certification Programs', Paper presented at the Transnational Business Governance Interactions workshop, European University Institute, May 2011.

Hall P. D. and D. W. Soskice (eds): 2001, Varieties of Capitalism: The Institutional Dimensions to Comparative Advantage, (Oxford: Oxford University Press). 
Hiss, S.: 2004, 'Corporate Social Responsibility: A Myth? The Example of the Roundtable Codes of Conduct in Germany', accessed at http://wrap.warwick.ac.uk/1974/.

Hughes, A., M. Buttle, and N. Wrigley: 2007, 'Organisational Geographies of Corporate Responsibility: A UK-US Comparison of Retailers Ethical Trading Initiatives', Journal of Economic Geography 7, 491-513.

Jackson, G. And R. Deeg: 2008, 'From Comparing Capitalisms to the Politics of Institutional Change', Review of International Political Economy 15(4), 680-709.

Jackson, G., and A. Apostolakou: 2010, 'Corporate Social Responsibility in Western Europe: CSR as an Institutional Mirror or a Substitute?', Journal of Business Ethics 94(3), 371-394.

Kang, N. and J. Moon: 2011, 'Institutional Complementarity between Corporate Governance and Corporate Social Responsibility: A Comparative Institutional Analysis of Three Capitalisms', Socio-Economic Review, doi: 10.1093/ser/mwr025.

Kinderman, D.: 2009, 'Why Do Some Countries Get CSR Sooner, and in Greater Quantity, than Others? The Political Economy of Corporate Responsibility and the Rise of Market Liberalism Across The OECD: 1977-2007', WZB Discussion Paper.

Kinderman, D.: 2011, “Free Us Up So We Can Be Responsible!” The Co-Evolution of Corporate Social Responsibility and Neo-Liberalism in the UK, 1977-2010', Socio-Economic Review doi: 10.1093/ser/mwr028.

King, G., R. O. Keohane and S. Verba: 1994, Designing Social Inquiry: Scientific Inference in Qualitative Research, Princeton, NJ: Princeton University Press.

Knopf J., W. Kahlenborn, T. Hajduk et al.: 2011, Corporate Social Responsibility: National Public Policies in the European Union. Brussels: European Commission; Directorate-General for Employment, Social Affairs and Inclusion.

Koch, D. J., J. Westeneng and R. Ruben: 2007, 'Does Marketisation of Aid Reduce the CountryLevel Poverty Targeting of Private Aid Agencies?', The European Journal of Development Research 19(4), 636-657.

Kolk, A.: 2011, 'Mainstreaming Sustainable Coffee', Forthcoming in Sustainable Development.

Kollman K. and A. Prakash: 2002, 'EMS-Based Environmental Regimes as Club Goods:

Examining Variations in Firm-Level Adoption of ISO 14001 and EMAS in UK, US, and Germany', Policy Sciences 35, 43-67.

Kriesi H., R. Koopmans, J. W. Duyvendak and M. G. Giugni: 1992, 'New Social Movements and Political Opportunities in Western Europe', European Journal of Political Research 22(2), 219-244. 
Lane, M. B.: 2003, 'Decentralization or Privatization of Environmental Governance? Forest Conflict and Bioregional Assessment in Australia', Journal of Rural Studies, 19(3), pp. 283-294.

Lee, M.-D. P. : 2011, 'Configuration of External Influences: The Combined Effects of Institutions and Stakeholders on Corporate Social Responsibility Strategies', Journal of Business Ethics, Forthcoming.

Lee, E. M., S.-Y. Park, M. I. Rapert and C. L. Newman: 2011, Does Perceived Consumer Fit Matter in Corporate Social Responsibility Issues? Journal of Business Research, Forthcoming.

MacDonald, K. and S. Marshall: 2010, Fair Trade, Corporate Accountability and Beyond: Experiments in Globalizing Justice, (Farnham: Ashgate).

Maignan I. and D. Ralston: 2002, 'Corporate Social Responsibility in Europe and the U.S.: Insights from businesses "Self-presentation", Journal of International Business Studies, 33: 498-514.

Mamic, I.: 2004, Implementing codes of conduct, (Sheffield: ILO \& Greenleaf).

Marini M. and B. Singer: 1988, 'Causality in the Social Sciences,', Sociological Methodology $18,347-409$.

Matten, D. and J. Moon: 2008, 'Implicit and Explicit CSR: A Conceptual Framework for a Comparative Understanding of Corporate Social Responsibility', Academy of Management Review 33(2), 404-424.

Micheletti, M.: 2003, Political Virtue and Shopping: Individuals, Consumerism and Collective Action, (New York: Palgrave Macmillan).

Middtun, A., K. Gautesen and M. Gjolberg: 2006, 'The Political Economy of CSR in Western Europe', Corporate Governance 6(4), 369-385.

Neumayer, E.: 2003, The Pattern of Aid Giving, (London: Routledge).

Nölke, A.: 2008, 'Private Governance in International Affairs and the Erosion of Coordinated Market Economies in the European Union', Mario Einaudi Center for International Studies Working Paper.

Overdevest, C.: 2010, 'Comparing Forest Certification Schemes: The Case of Ratcheting Standards in the Forest Sector', Socio-Economic Review 8, 47-76. 
Overdevest, C. and M. G. Rickenbach: 2006, 'Forest Certification and Institutional Governance: An Empirical Study of Forest Stewardship Council Certificate Holders in the United States', Forest Policy and Economics 9(1): 93-102.

Parsons, W.: 1995, Public Policy: An Introduction to the Theory and Practice of Policy Analysis, (Brookfield and Aldershot: Edward Elgar).

Prakash, A. and M. Potoski: 2007, 'Collective Action Through Voluntary Environmental Programs: A Club Theory Perspective’, Policy Studies Journal 35(4), 773-792.

Sasser, E., A. Prakash, B. Cashore, and G. Auld: 2006, 'Direct Targeting as an NGO Political Strategy: Examining Private Authority Regimes in the Forestry Sector', Business and Politics 8, $1-32$.

Scharpf, F. W.: 1997, Games Real Actors Play: Actor-Centered Institutionalism in Policy Research, (Boulder: Westview).

Steen Knudsen, J. and D. Brown: 2011, 'CSR Initiatives and National Institutions: Do Corporate Activities Reflect the Welfare Goals of the State?', presented at the Society for the Advancement of Socio-Economics (SASE) Annual Conference, June 23-25, Madrid.

Steuer, R.: 2010, 'The Role of Governments in Corporate Social Responsibility: Characterising Public Policies on CSR in Europe', Policy Sciences 43, 49-72.

Van Tulder, R. and A. Van der Zwart: 2006, International Business-Society Management:

Linking Corporate Responsibility and Globalization, (Routledge, London).

Whitley, R. : 1999, Divergent capitalisms, (Oxford University Press, Oxford).

Witt, M. A. and G. Redding: 2011, 'The Spirits of Corporate Social Responsibility: Senior Executive Perceptions of the Role of the Firm in Society in Germany, Hong Kong, Japan, South Korea and the USA', Socio-Economic Review doi: 10.1093/ser/mwr026.

Zeitlin, J.: 2011, 'Presidential Address: Pragmatic Transnationalism: Governing

Across Borders in the Global Economy', Socio-Economic Review 9, 1-20. 


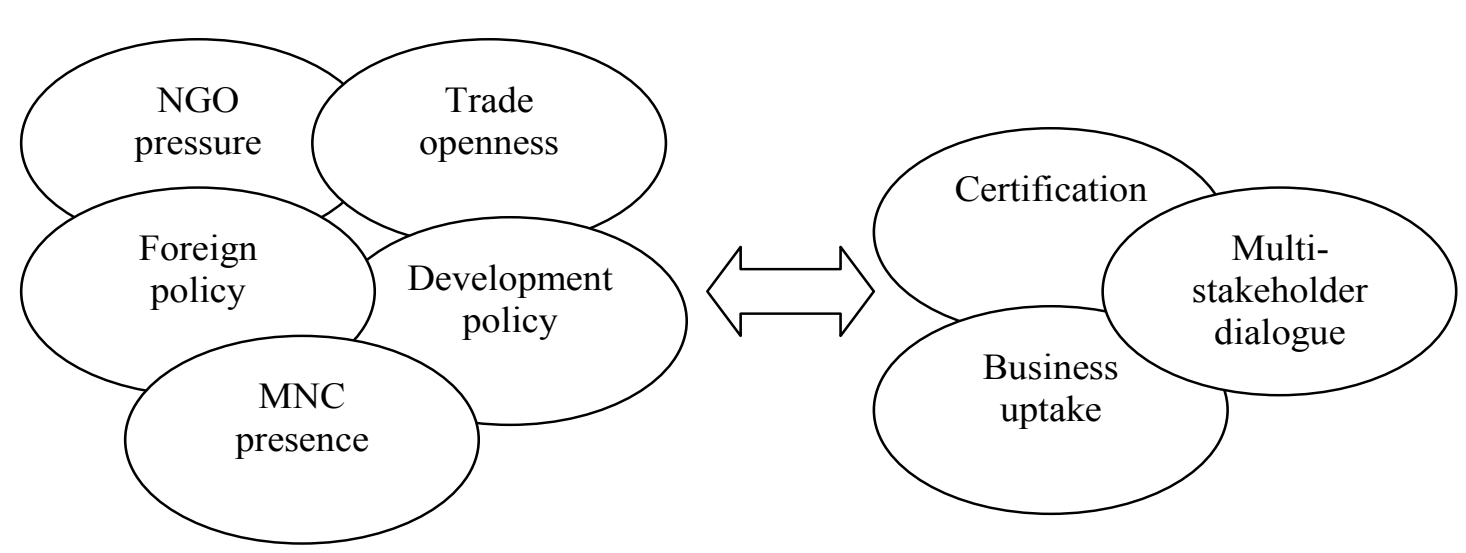

Figure One. National-institutional ensembles related to development policy and their relationship to CSR practices.

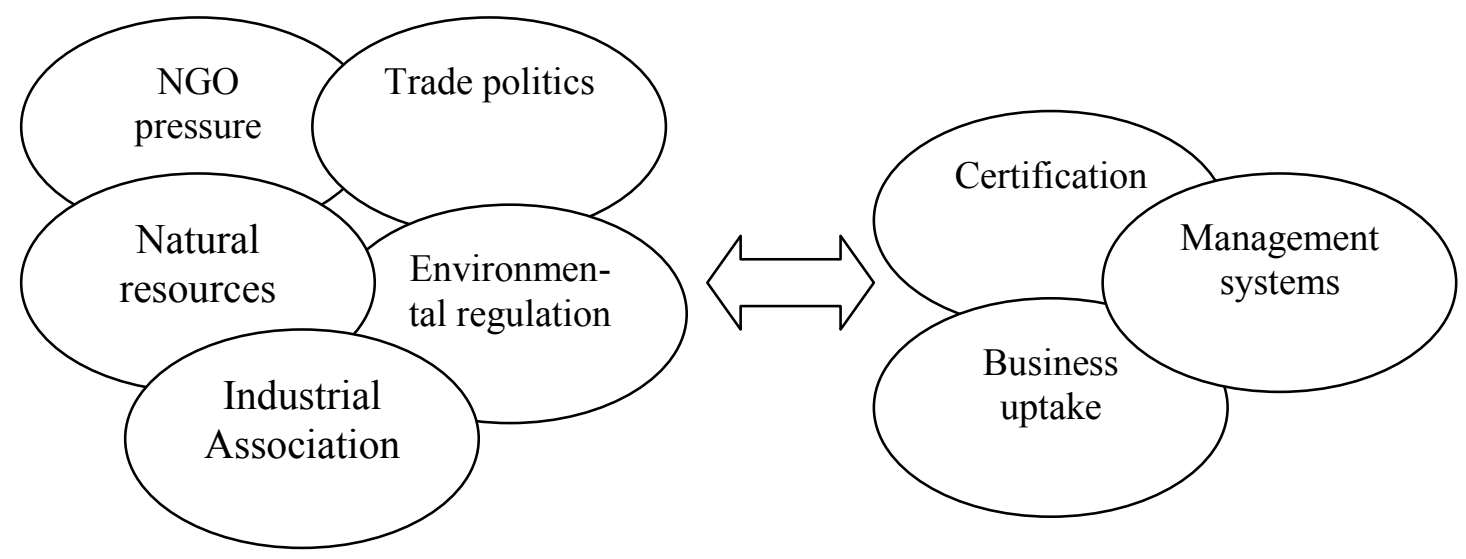

Figure Two. National-institutional ensembles and their relationship to environmental aspects of CSR practices. 


\begin{tabular}{|c|c|c|}
\hline & Gaps in our understanding & Proposal to help fill gaps \\
\hline \multirow[t]{3}{*}{$\begin{array}{l}\text { National institutions } \\
\text { affecting CSR }\end{array}$} & $\begin{array}{l}\text { Unknown how institutions } \\
\text { not treated in Comparative } \\
\text { Capitalism-literature affect } \\
\text { CSR }\end{array}$ & $\begin{array}{l}\text { Disaggregation of national } \\
\text { institutions for empirical } \\
\text { analysis }\end{array}$ \\
\hline & $\begin{array}{l}\text { State institutions } \\
\text { underemphasized due to } \\
\text { VoC-emphasis }\end{array}$ & $\begin{array}{l}\text { Usage of analysis of specific } \\
\text { CSR practices to hypothesize } \\
\text { effect of institutions other } \\
\text { than treated in Comparative } \\
\text { Capitalism literature }\end{array}$ \\
\hline & $\begin{array}{l}\text { VoC-emphasis complicates } \\
\text { analysis of CSR as } \\
\text { institutional change }\end{array}$ & \\
\hline \multirow[t]{2}{*}{$\begin{array}{l}\text { CSR practices affected by } \\
\text { national institutions }\end{array}$} & $\begin{array}{l}\text { Unknown how different } \\
\text { aspects of CSR practices may } \\
\text { relate in different ways to } \\
\text { national institutions }\end{array}$ & $\begin{array}{l}\text { Disaggregation of } \\
\text { measurement of CSR } \\
\text { practices for empirical } \\
\text { analysis }\end{array}$ \\
\hline & $\begin{array}{l}\text { Unknown whether one aspect } \\
\text { of CSR practices affected by } \\
\text { national institutions may be } \\
\text { generalizable for other } \\
\text { aspects }\end{array}$ & $\begin{array}{l}\text { Usage of analyses of specific } \\
\text { CSR practices to hypothesize } \\
\text { differences between aspects } \\
\text { of CSR practices }\end{array}$ \\
\hline \multirow[t]{2}{*}{$\begin{array}{l}\text { Causal link between the } \\
\text { two }\end{array}$} & $\begin{array}{l}\text { Unknown what causal chain } \\
\text { between national institutions } \\
\text { and CSR actually looks like }\end{array}$ & $\begin{array}{l}\text { Usage of process and } \\
\text { diachronic analysis }\end{array}$ \\
\hline & $\begin{array}{l}\text { Process analysis } \\
\text { underemphasized due to } \\
\text { predominance of static data }\end{array}$ & $\begin{array}{l}\text { Large } \mathrm{N} \text {-analysis based on } \\
\text { propositions from process } \\
\text { and diachronic analysis }\end{array}$ \\
\hline
\end{tabular}

Table One. Gaps in our understanding and proposals to help fill them 